\title{
Tanggung Jawab Notaris Dalam Pelanggaran Kode Etik Notaris
}

\section{Latifah}

Program Magister Kenotariatan Fakultas Hukum Universitas Islam Indonesia Yogyakarta Indonesia Jln. Cik Di Tiro No. 1 Yogyakarta 55283 Indonesia latifahbarlian14@gmail.com

\begin{tabular}{ll}
\hline Key Word: & Abstract \\
Code of ethics; & Violations committed by Notary related to the code of ethics are actions that need to \\
notary; & be followed up and monitored by the Notary Honorary Council, so that in the future \\
responsibility; & there will be no more violations and so that the level of discipline will increase and \\
violation & become an example for new Notaries. In addition, the role of the Notary Honorary \\
& Council as a supervisor and providing sanctions for violations to Notaries is still \\
& lacking because in practice the Honorary Council still has to coordinate with the \\
& Notary Supervisory Council to impose sanctions. Therefore, an interesting problem \\
& arises, first, what is the risk borne by a notary if there is a violation of the code of \\
& ethics? Second, how is the implementation of the sanctions imposed by the Notary \\
& Honorary Council against a notary who is proven to have violated the code of \\
& ethics? This research is an empirical juridical research using a statutory and \\
& conceptual approach. The results of this study conclude that, first, notaries who \\
& violate the Notary Code of Ethics can be subject to ethical sanctions from the Notary \\
& Honorary Council. Second, the Notary Honorary Council must continue to \\
coordinate with the Notary Supervisory Council in imposing ethical sanctions and \\
notaries who are subject to ethical sanctions can file an appeal.
\end{tabular}

\begin{tabular}{ll}
\hline Kata-kata Kunci: & Abstrak \\
\cline { 2 - 3 } $\begin{array}{l}\text { Kode etik; } \\
\text { notaris; }\end{array}$ & Pelanggaran yang dilakukan Notaris terkait kode etik adalah perbuatan \\
pelanggaran; & yang perlu ditindak lanjuti dan di awasi oleh Dewan Kehormatan Notaris, \\
tanggung jawab & agar kedepannya tidak terjadi kembali pelanggaran dan sehingga tingkat \\
& kedisplinan semakin meningkat dan menjadi contoh untuk notaris baru. \\
& Selain itu, peran Dewan Kehormatan Notaris juga sebagai pengawas dan \\
& memberikan sanksi atas pelanggaran kepada Notaris masih kurang karena \\
& pada praktiknya Dewan Kehormatan masih harus berkoordinasi pada \\
& Majelis Pengawas Notaris untuk menjatuhkan sanksi. Oleh karena itu \\
& timbul permasalahan menarik, pertama, bagaimana risiko yang dipikul \\
& notaris jika terjadi pelanggaran kode etik? Kedua, bagaimana pelaksanaan \\
& sanksi yang dijatuhkan oleh Dewan Kehormatan Notaris terhadap notaris \\
& yang terbukti melakukan pelanggaran kode etik? Penelitian ini merupakan \\
& penelitian yuridis empiris dengan menggunakan metode pendekatan \\
& perundang-undangan dan konseptual. Hasil dalam penelitian ini \\
& menyimpulkan, pertama, notaris yang melanggar Kode Etik Notaris dapat \\
& dijatuhi sanksi etik dari Dewan Kehormatan Notaris. Kedua, Dewan \\
& Kehormatan Notaris harus tetap berkoodinasi dengan Majelis Pengawas \\
& Notaris dalam menjatuhkan sanksi etik dan notaris yang dijatuhi sanksi etik \\
dapat mengajukan banding.
\end{tabular}

\section{Pendahuluan}

Negara Republik Indonesia sebagai negara hukum menjamin kepastian, ketertiban dan perlindungan hukum bagi setiap warga negara. Untuk menjamin ketertiban dan perlindungan hukum dibutuhkan alat bukti tertulis yang bersifat autentik mengenai perbuatan, perjanjian, penetapan dan peristiwa hukum yang dibuat dihadapan atau oleh 
pejabat yang berwenang. ${ }^{1}$ Pejabat notaris dalam pembuatan alat bukti tertulis yang bersifat autentik mengenai keadaan, peristiwa, atau perbuatan hukum yang diselenggarakan melalui jabatan tertentu diperlukan untuk menjamin perlindungan hukum tersebut.

Istilah notaris berasal dari perkataan "nola litcraria", yang berarti tanda (letter merk atau karakter) yang menyatakan sesuatu perkataan. ${ }^{2}$ Pasal 1 angka 1 dalam UndangUndang Nomor 2 Tahun 2014 tentang Perubahan Atas Undang-undang Nomor 30 Tahun 2004 tentang Jabatan Notaris (untuk selanjutnya disebut UUJN) menyatakan bahwa notaris adalah pejabat umum yang berwenang untuk membuat akta autentik dan memiliki kewenangan lainnya sebagaimana dimaksud dalam undang-undang ini atau berdasarkan undang-undang lainnya. Istilah akta autentik dalam bahasa Inggris, disebut dengan authentic deed, sedangkan dalam bahasa Belanda, disebut dengan authentieke akte van, yang telah diatur dalam Pasal 1868 Kitab Undang-Undang Hukum Perdata (untuk selanjutnya disebut dengan KUHPerdata) dan berbagai peraturan perundang-undangan lainnya. ${ }^{3}$

Jabatan notaris merupakan jabatan kepercayaan yang harus selaras dengan mereka yang menjalankan tugas jabatan notaris sebagai orang yang dapat dipercaya bukan sebagai orang yang tidak dapat dipercaya, sehingga hal tersebut, antara jabatan notaris dan pejabatnya harus sejalan bagaikan dua sisi mata uang yang tidak dapat dipisahkan. ${ }^{4}$ Seorang notaris dalam menjalankan jabatannya harus patuh dan tunduk pada UUJN, namun disisi lain seorang notaris dalam bertindak sebagai seorang pejabat umum juga diatur oleh kode etik yang berperan untuk menciptakan suatu standar bagi para profesional yang berada dalam organisasi tersebut.

Moral hakikatnya berkaitan erat dengan etika yang mempunyai 2 makna. Pertama, sebagai suatu kumpulan mengenai penilaian terhadap perbuatan manusia. Kedua, bersifat etik yang digunakan untuk membedakan perbuatan-perbuatan manusia mengenai nilai-nilai dan norma-norma etis yang bersifat susila dan harus ditunjang oleh integritas moral yang tinggi. ${ }^{5}$ Kode etik notaris diatur oleh organisasi profesi notaris dalam hal ini Ikatan Notaris Indonesia (selanjutnya disebut INI) pada Kongres Luar Biasa Ikatan Notaris Indonesia yang diselenggarakan pada 2015. Terdapat 2 Kedudukan kode etik bagi notaris:

1. karena sifat dan hakekat dari pekerjaan notaris yang sangat berorientasi pada legalisasi, sehingga dapat menjadi fundamen hukum utama tentang status harta benda, hak, dan kewajiban seorang para pihak yang menggunakan jasa notaris tersebut.

2. agar tidak terjadi ketidakadilan sebagai akibat dari pemberian status harta benda, hak dan kewajiban yang tidak sesuai dengan kaidah dan prinsip-prinsip hukum hlm. 1.

${ }^{1}$ M. Luthfan Hadi Darus, Hukum Notariat Dan Tanggungjawab Jabatan Notaris, UII Press, Yogyakarta, 2017,

2 R. Soegondo Notodisoerjo, Hukum Notariat di Indonesia Suatu Penjelasan, Rajawali, Jakarta, 1999, hlm. 13.

${ }^{3}$ H.S. Salim, Teknik Pembuatan Akta Satu Konsep Teoritis, Kewenangan Notaris, Bentuk dan Minuta Akta, PT Rajagrafindo Persada, Jakarta, 2015, hlm. 17.

${ }^{4}$ Habib Adjie, Hukum Notaris Indonesia (Tafsir Tematik Terbadap UU No. 30 Tahun 2004 Tentang Jabatan Notaris), Cetakan Pertama, Refika Aditama, Bandung, 2008, hlm. 35.

5 Ibid., hlm. 194. 
dan keadilan, sehingga dapat mengacaukan hak-hak pribadi dari masyarakat pencari keadilan, maka bagi dunia notaris sangat diperlukan juga suatu kode etik profesi yang baik dan modern. ${ }^{6}$

Pasal 1 ayat (8) Kode Etik Notaris INI menegaskan bahwa bila notaris melakukan pelanggaran kode etik maka akan ditindak lanjuti oleh penegak Kode Etik Notaris INI yaitu Dewan Kehormatan Notaris. Pengawasan terhadap notaris dalam Kode Etik Notaris INI, diatur dalam Pasal 7 Kode Etik Notaris INI yang memuat lembaga yang dapat melakukan pengawasan terhadap notaris yaitu Dewan Kehormatan. Namun, ketentuan pasal selanjutnya tidak menjelaskan secara rinci bagaimana kewenangan dan kewajibannya dari Dewan Kehormatan. Praktik yang terjadi di lapangan, Dewan Kehormatan hanya menerima laporan saja dari masyarakat. Apabila benar terjadi pelanggaran yang dilakukan oleh notaris maka Dewan Kehormatan akan menindak dan memberikan sanksi. Sanksi yang diberikan kepada notaris yang melakukan pelanggaran berupa:

1. Teguran

2. Peringatan

3. Pemberhentian sementara dari keanggotaan Perkumpulan

4. Pemberhentian dengan hormat dari keanggotaan Perkumpulan

5. Pemberhentian dengan tidak hormat dari keanggotaan Perkumpulan.

Permasalahan yang kemudian muncul adalah, tidak terdapat peraturan khusus yang menjadi dasar pelaksanaan bagi Dewan Kehormatan dalam menjalankan kewenangannya serta bagaimana bentuk pelaksanaan 5 sanksi pelanggaran kode etik yang diterima seorang Notaris sehingga berpotensi mengakibatkan beragamnya pelaksanaan kewenangan yang dilakukan.

\section{Rumusan Masalah}

Berdasarkan uraian latar belakang masalah yang telah penulis uraikan di atas, penulis tertarik untuk membahas masalah tersebut lebih lanjut dengan menitikberatkan pada rumusan masalah, pertama, bagaimana risiko yang dipikul notaris jika terjadi pelanggaran kode etik? Kedua, bagaimana pelaksanaan sanksi yang dijatuhkan oleh Dewan Kehormatan Notaris terhadap notaris yang terbukti melakukan pelanggaran kode etik?

\section{Tujuan Penelitian}

Dari perumusan permasalahan yang telah diuraikan diatas, maka tujuan penelitian ini yakni, pertama, untuk mengetahui risiko yang diterima notaris apabila melakukan pelanggaran kode etik. Kedua, untuk mengetahui bagaimana pelaksanaan sanksi yang dijatuhkan oleh Dewan Kehormatan Notaris terhadap notaris yang terbukti melakukan pelanggaran kode etik.

${ }^{6}$ Yogi Priyambodo dalam Munir Fuady, Profesi Mulia (Etika Profesi Hukum bagi Hakim, Jaksa, Advokat, Notaris, Kurator dan Pengurus), PT. Citra Aditya Bakti, Bandung, 2005, hlm. 133. 


\section{Metode Penelitian}

Penelitian ini merupakan penelitian hukum empiris dengan metode pendekatan perundang-undangan dan konseptual. Data yang digunakan dalam penelitian ini adalah data sekunder, di samping itu juga digunakan data primer sebagai pelengkap dalam penelitian ini. Adapun sumber data diperoleh melalui dua cara, yaitu metode penelitian kepustakaan dan penelitian lapangan, penelitian kepustakaan adalah suatu cara pengumpulan data sekunder yang dilakukan dengan mempelajari bahan hukum primer dan bahan hukum sekunder.

\section{Hasil Penelitian dan Pembahasan}

\section{Risiko yang Dipikul oleh Notaris bila Melakukan Pelanggaran Kode Etik}

Notaris sebagai pejabat umum dalam melaksanakan tugas jabatannya harus tunduk dan patuh pada kaidah hukum yang tercantum dalam UUJN. Pentingnya seorang notaris untuk tunduk pada peraturan yang tercantum dalam UUJN tidak lain karena beratnya beban tanggung jawab dari seorang notaris yang berwenang untuk membuat akta autentik yang dibuat kerap kali dijadikan 'kunci emas' dalam proses persidangan. Beratnya tanggung jawab tersebut, mewajibkan seorang notaris juga harus patuh pada kode etik profesi notaris terutama pada hal-hal yang dilarang untuk dilakukan oleh seorang notaris sebagaimana diatur dalam Bab III Pasal 4 Kode Etik yakni:

1. Mempunyai lebih dari 1 kantor, baik kantor cabang ataupun kantor perwakilan;

2. Memasang papan nama dan/atau tulisan yang berbunyi "Notaris/Kantor Notaris" di luar lingkungan kantor;dan

3. Melakukan publikasi atau promosi diri, baik sendiri maupun secara bersamasama, dengan mencantumkan nama dan jabatannya, menggunakan sarana media cetak dan/atau elektronik dalam bentuk:

a. Iklan

b. Ucapan selamat

c. Ucapan belasungkawa

d. Ucapan terimakasih

e. Kegiatan pemasaran

f. Kegiatan sponsor, baik dalam bidang sosial, keagamaan, maupun olahraga.

g. Bekerjasama dengan biro jasa/orang/Badan Hukum yang pada hakekatnya bertindak sebagai perantara untuk mencari atau mendapatkan klien.

Segala sesuatu yang diatur dalam larangan tersebut, merupakan sumber pelanggaran bagi seorang notaris untuk dapat ditindak dan mendapatkan sanksi secara etik oleh Dewan Kehormatan Notaris yang selanjutnya disebut DKN. Apabila dicermati dari keseluruhan larangan yang diatur dalam kode etik, ruang lingkup larangan sebagian besar melarang seorang notaris untuk melakukan promosi dan publikasi terkait dengan kantor dan jabatannya sebagai notaris.

Meskipun telah terdapat aturan yang melarang tingkah laku seorang notaris sebagaimana tercantum dalam kode etik tersebut di atas, namun hingga kini masih banyak terdapat notaris yang melakukan pelanggaran. Berdasarkan keterangan dari 
Narasumber Jetti yang merupakan notaris di Kota Tasikmalaya, beliau pernah melanggar salah satu ketentuan dalam kode etik yakni aturan tentang ukuran papan nama. Dijelaskan oleh Jetti bahwa atas pelanggaran papan nama yang dilakukan tersebut, beliau diberi sanksi teguran dan diminta untuk segera mengganti papan nama dengan ukuran yang sesuai dengan ketentuan kode etik. ${ }^{7}$

Tidak hanya Jetti yang pernah mendapatkan teguran, hal serupa juga pernah diketahui oleh Notaris Basri Jayasantana, Notaris di Kabupaten Ciamis. Berdasarkan keterangan beliau, disampaikan bahwa beliau pernah mengetahui salah satu rekan notarisnya mengirimkan karangan bunga dengan mencantumkan nama dan jabatannya selaku notaris sebagai wujud apresiasinya terhadap usaha rekannya yang membuka usaha baru. Lebih lanjut disampaikan oleh beliau bahwa atas pelanggaran yang dilakukan rekannya tersebut telah diberi sanksi berupa teguran. ${ }^{8}$

Terdapat 5 sanksi dalam Kode Etik Notaris yang tersusun secara hierarki berdasarkan tingkat pelanggaran paling rendah hingga ke tingkat pelanggaran paling berat yang dijatuhkan apabila seorang notaris melakukan pelanggaran kode etik yakni:

1. Teguran

2. Peringatan

3. Pemberhentian sementara dari keanggotaan Perkumpulan

4. Pemberhentian dengan hormat dari keanggotaan Perkumpulan

5. Pemberhentian dengan tidak hormat dari keanggotaan Perkumpulan.

Disampaikan oleh seorang narasumber yaitu salah satu notaris di Kota Tasikmalaya, untuk selanjutnya disebut narasumber Heri Hendriyana bahwa sanksi teguran adalah sanksi yang paling ringan karena disampaikan secara lisan ${ }^{9}$. Namun disisi lain, tidak hanya DKN yang pernah memberikan teguran, namun teguran juga dilakukan oleh fungsionaris organisasi INI secara langsung. Disampaikan juga oleh seorang narasumber yakni Tiana selaku notaris di Kabupaten Tasikmalaya, bahwa dikarenakan teguran bersifat langsung, maka menurut keterangan narasumber Tiana sering kali atas pelanggaran yang dilakukan ini tidak memerlukan diskusi rapat dari internal DKN sebelum menjatuhkan sanksi teguran. ${ }^{10}$

Sanksi yang kedua yakni peringatan secara tertulis oleh DKN kepada notaris yang bersangkutan. Berbeda dengan teguran, menurut Heri Hendriyana untuk menjatuhkan sanksi peringatan ini, DKN memerlukan rapat internal terlebih dahulu sebelum menjatuhkan sanksi peringatan. ${ }^{11}$ Hal ini dikarenakan pada sanksi peringatan, DKN mencantumkan identitas DKN pada surat peringatan yang dikirimkan kepada notaris yang melakukan pelanggaran.

Sanksi yang ketiga yaitu pemberhentian sementara dari keanggotaan perkumpulan atau kerap disebut skors dari keanggotaan perkumpulan. Dijelaskan oleh Heri Hendriyana bahwa sejauh pengetahuan beliau, sanksi pemberhentian sementara ini hanya bersifat internal organisasi saja yakni tidak diikut sertakan dalam seluruh kegiatan

\footnotetext{
${ }^{7}$ Wawancara dengan Jetti Widiastuti selaku Notaris Kota Tasikmalaya, 28 Januari 2021, pukul 09.00 WIB

${ }^{8}$ Wawancara dengan Basri Jayasantan selaku Notaris Kabupaten Ciamis, 29 Januari 2021, pukul 09.30 WIB

${ }^{9}$ Wawancara dengan Heri Hendriyana selaku Notaris Kota Tasikmalaya, 29 Januari 2021, pukul 10.30 WIB

${ }^{10}$ Wawancara dengan Tiana selaku Notaris Kota Tasikmalaya, 29 Januari 2021, pukul 13.00 WIB

${ }^{11}$ Wawancara dengan Heri Hendriyana selaku Notaris Kota Tasikmalaya, 29 Januari 2021, pukul 10.30 WIB
} 
organisasi selama masa skors tersebut masih berlangsung.12 Atas skors tersebut tidak berpengaruh dengan jabatan seorang notaris, dengan kata lain notaris masih dapat membuka kantor dan menjalankan jabatannya seperti biasa.

Sanksi yang keempat dan kelima yakni pemberhentian dengan hormat dari keanggotaan perkumpulan dan pemberhentian dengan tidak hormat dari keanggotaan perkumpulan. Setelah sanksi pelanggarannya telah diputuskan oleh DKN, maka DKN akan melakukan pemberitahuan pemberhentian kepada Majelis Pengawas. Menurut keterangan Heri Hendriyana atas pemberhentian tersebut apabila Majelis Pengawas tidak menindaklanjuti pemberitahuan pemberhentian tersebut, maka notaris yang diberi sanksi tersebut tetap dapat melakukan tugas jabatannya sebagai notaris, meskipun begitu notaris yang bersangkutan tetap tidak dianggap sebagai anggota perkumpulan.13

Berdasarkan hasil penelitian di atas, dapat digaris bawahi bahwa hingga kini notaris di beberapa daerah masih belum mengetahui secara jelas tentang parameter pelanggaran yang seperti apa yang mendapatkan sanksi teguran, peringatan, pemberhentian sementara dari anggota perkumpulan, pemberhentian dengan hormat dari anggota perkumpulan dan pemberhentian tidak hormat dari anggota perkumpulan karena hal tersebut sesuai dengan hasil keputusan DKN. Atas penjatuhan sanksi yang berhubungan dengan pemberhentian sementara atau dengan hormat atau dengan tidak hormat dari perkumpulan tidak berarti notaris yang bersangkutan tidak dapat menjalankan jabatannya sebagai notaris, karena yang memiliki kewenangan untuk memberhentikan seorang notaris dari jabatannya yaitu Kementerian Hukum dan Hak Asasi Manusia Republik Indonesia saja.

\section{Pelaksanaan Sanksi dari Dewan Kehormatan Notaris}

Dewan Kehormatan berwenang melakukan pemeriksaan atas pelanggaran terhadap kode etik dan menjatuhkan sanksi kepada pelanggarnya sesuai dengan kewenangannya dan bertugas untuk:

1. Melakukan pembinaan, bimbingan, pengawasan, pembenahan anggota dalam menjunjung tinggi kode etik.

2. Memeriksa dan mengambil keputusan atas dugaan pelanggaran ketentuan kode etik yang bersifat internal atau yang tidak mempunyai masyarakat secara langsung.

3. Memberikan saran dan pendapat kepada majelis pengawas atas dugaan pelanggaran kode etik dan jabatan notaris.

Dewan Kehormatan terbagi atas:

1. Pada tingkat pertama oleh Dewan Kehormatan Daerah (DKD)

2. Pada tingkat banding oleh Dewan Kehormatan Wilayah

3. Pada tingkat terakhir oleh Dewan Kehormatan Pusat.

Pengurus Daerah INI mempunyai DKD pada setiap kepengurusan. DKD terdiri dari 3 orang anggota diantaranya, seorang ketua, seorang wakil ketua, dan seorang sekretaris. Anggota yang dapat diangkat menjadi anggota DKD adalah anggota biasa

12 Wawancara dengan Heri Hendriyana selaku Notaris Kota Tasikmalaya, 29 Januari 2021, pukul 10.30 WIB

${ }^{13}$ Wawancara dengan Heri Hendriyana selaku Notaris Kota Tasikmalaya, 29 jJnuari 2021, pukul 10.30 WIB 
yang telah menjabat sebagai notaris sekurang-kurangnya 5 tahun dan anggota luar biasa (mantan notaris), yang senantiasa mentaati peraturan perkumpulan dan peraturan perundang-undangan yang berlaku, berdedikasi tinggi, berjasa dan loyal serta mempunyai rasa kepedulian yang tinggi kepada perkumpulan. ${ }^{14}$

DKD merupakan badan yang bersifat otonom di dalam mengambil keputusan yang mempunyai tugas dan kewajiban untuk memberikan bimbingan dari melakukan pengawasan dalam pelaksanaan serta pentaatan Kode Etik oleh para anggota perkumpulan di daerah masing-masing. DKD dalam menjalankan tugas dan kewajibannya berwenang untuk: 15

1. Memberikan dan menyampaikan usul dan saran yang ada hubungannya dengan kode etik dan pembinaan rasa kebersamaan profesi (corpsgeest) kepada Pengurus Daerah.

2. Memberikan peringatan, baik secara tertulis maupun dengan lisan secara langsung kepada para anggota di daerah masing-masing yang melakukan pelanggaran atau melakukan perbuatan yang tidak sesuai dengan kode etik atau bertentangan dengan rasa kebersamaan profesi.

3. Memberitahukan tentang pelanggaran tersebut kepada Pengurus Daerah, Pengurus Wilayah, Dewan Kehormatan Wilayah, Pengurus Pusat dan Dewan Kehormatan Pusat.

4. Mengusulkan kepada Pengurus Pusat melalui Dewan Kehormatan Wilayah dan Dewan Kehormatan Pusat untuk pemberhentian sementara anggota perkumpulan yang melakukan pelanggaran terhadap kode etik.

Dalam rangka menjalankan tugas dan kewajibannya, DKD menerima laporan dari masyarakat atau Majelis Pengawas apabila ada yang melakukan pelanggaran, selanjutnya oleh DKD menindak lanjutinya dengan mencari fakta atas pelanggaran yang terjadi tersebut. Setelah menemukan fakta-fakta pelanggaran kode etik atau setelah menerima pengaduan, DKD memanggil anggota yang bersangkutan untuk memastikan apakah betul telah terjadi pelanggaran dan memberikan kesempatan kepadanya untuk memberikan penjelasan dan pembelaan. Namun, bila notaris pada panggilan pertama tidak diindahkan maka akan ada pemanggilan kedua, namun menurut Heri Hendriyana bila ada terjadi pelanggaran biasanya notaris langsung datang saat panggilan pertama sehingga laporan yang masuk bisa langsung ditindak lanjuti.16

Setelah pertemuan tersebut DKD membuat risalah yang ditandatangani oleh anggota yang bersangkutan dan ketua serta seorang anggota DKD. DKD diwajibkan untuk memberikan keputusan dalam waktu tiga puluh hari setelah pengaduan diajukan. Dalam menangani kasus ini, DKD harus tetap menghormati dan menjunjung tinggi martabat yang bersangkutan, selalu menjaga suasana kekeluargaan serta merahasiakan segala sesuatu yang ditemukannya. Hal ini karena seorang notaris yang diduga melakukan pelanggaran Kode Etik hendaknya diberikan pendampingan oleh perkumpulan dengan menjunjung asa praduga tak bersalah. ${ }^{17}$

\footnotetext{
${ }^{14}$ Anggaran Dasar Ikatan Notaris Indonesia, Hasil Kongres Luar Biasa Bandung 27 Januari 2005

15 Ibid.

16 Wawancara dengan Heri Hendriyana selaku Notaris Kota Tasikmalaya, 29 Januari 2021, pukul 10.30 WIB

17 Alief Latief, "Main Bajak Karyawan Dan Kode Etik Notaris Dan/PPAT", Renvoi, Juli 2004, hlm. 3.
} 
DKD berkoordinasi dengan Majelis Pengawas Daerah (MPD) untuk melakukan pemeriksaan atas pelanggaran yang terjadi serta dapat menjatuhkan sanksi kepada notaris. Apabila ada anggota yang diduga melakukan pelanggaran terhadap Kode Etik, baik dugaan tersebut berasal dari pengetahuan DKD sendiri maupun karena laporan dari Pengurus Daerah ataupun pihak lain kepada DKD, maka selambat-lambatnya dalam waktu 7 hari kerja DKD wajib segera mengambil tindakan dengan mengadakan sidang.

Sidang ini dilakukan untuk menindaklanjuti tentang dugaan pelanggaran yang terjadi, bila dalam kurun waktu 7 hari setelah tanggal ditentukan maka DKD akan memangil notaris yang bersangkutan dengan surat tercatat atau ekspedisi, untuk keterangannya membela diri. DKD baru akan menentukan putusannya mengenai terbukti ada tidaknya pelanggaran kode etik serta penjatuhan sanksi terhadap pelanggarnya (apabila terbukti), setelah mendengar keterangannya dan pembelaan diri dari anggota yang bersangkutan dalam sidang DKD.

Terhadap sanksi pemberhentian sementara atau pemecatan (onzetting) dari keanggotaan perkumpulan diputuskan, DKD wajib berkonsultasi terlebih dahulu dengan pengurus daerahnya. Putusan sidang DKD wajib dikirim oleh DKD kepada anggota yang melanggar dengan surat tercatat atau dengan ekspedisi dan tembusannya kepada pengurus cabang, pengurus daerah, pengurus pusat dan dewan kehormatan pusat, semuanya itu dalam waktu tujuh hari kerja, setelah dijatuhkan putusan oleh sidang DKD.

Menurut Heri Hendriyana, apabila terjadi skors maka notaris tersebut tidak melakukan hal apapun, namun apabila ada klien yang datang untuk meminta salinan akta maka akan diberikan karena menurut beliau itu tidak masalah karena aktanya sudah pernah dibuat oleh notaris dan klien tidak perlu khawatir karena walau di skors salinan yang dibuat tetap sah dan bisa ditanda tangani. Selain itu, beliau menambahkan bila ada akta yang belum terselesaikan maka harus diselesaikan terlebih dahulu. ${ }^{18}$

Basri Jayasanta juga menambahkan, bahwa pada kenyataannya di Ciamis peran DKD dalam menjatuhkan sanksi masih harus berkoordinasi dengan Majelis Pengawas tidak bisa langsung menjatuhkan sanksi begitu saja. DKD disini hanya menjadi wadah atau menampung laporan-laporan pelanggaran. Dari hasil pemeriksaan dan proses sidang tersebut, maka dapat dijadikan landasan oleh DKN untuk memberikan putusan untuk melakukan pemecatan sebagai notaris kepada Menteri Hukum dan Hak Asasi Manusia Republik Indonesia.

Proses pemeriksaan yang dilakukan pada tingkat pertama dan banding adalah guna untuk melindungi hak asasi dari notaris. ${ }^{19}$ Namun, bila putusan yang berisi penjatuhan sanksi pemecatan sementara atau pemecatan dari keanggotaan pekumpulan dapat diajukan banding kepada DKW. Permohonan ini wajib dilakukan oleh anggota yang bersangkutan dalam waktu tiga puluh hari kerja, setelah tanggal penerimaan surat putusan penjatuhan sanksi. Permohonan ini dikirim dengan surat tercatat atau dikirim langsung oleh anggota yang bersangkutan kepada DKW dan tembusannya kepada DKP, pengurus wilayah dan pengurus daerah. DKD dalam waktu tujuh hari setelah menerima

18 Wawancara dengan Heri Hendriyana selaku Notaris Kota Tasikmalaya, 29 Januari 2021, pukul 10.30 WIB

${ }^{19}$ Wawancara dengan Basri Jayasantana selaku Notaris Kabupaten Ciamis, 29 Januari 2021, pukul 10.30 WIB 
surat tembusan permohonan banding wajib mengirim semua salinan berkas pemeriksaan kepada DKP.

Setelah menerima permohonan banding, DKW wajib memanggil anggota yang naik banding, selambat-lambatnya dalam waktu tujuh hari kerja, setelah menerima permohonan tersebut. Anggota yang mengajukan banding dipanggil untuk didengar keterangannya dan diberi kesempatan untuk membela diri dalam siding DKW. DKW wajib memberi putusan dalam tingkat banding melalui sidangnya, dalam waktu tiga puluh hari kerja, setelah anggota yang bersangkutan didengar keterangannya dan diberi kesempatan untuk membela diri. Apabila anggota yang dipanggil tidak datang dan tidak member kabar dengan alasan yang sah melalui surat tercatat, maka sidang DKW, tetap akan memberi putusan dalam waktu yang ditentukan.

DKW wajib mengirimkan putusannya kepada anggota yang minta banding dengan surat tercatat atau dengan ekspedisian tembusannya kepada DKD, Pengurus Wilayah, Pengurus Daerah dan Pengurus Pusat INI, semuanya itu dalam waktu tujuh hari kerja setelah sidang DKW menjatuhkan keputusannya atas banding tersebut. Apabila pemeriksaan dan penjatuhan sanksi dalam tingkat pertama telah dilakukan oleh DKW, berhubung pada tingkat kepengurusan daerah yang bersangkutan belum dibentuk DKD, maka keputusan DKW tersebut merupakan keputusan tingkat banding.

Apabila kongres memutuskan anggota yang diberhentikan sementara itu tidak bersalah, maka anggota yang bersangkutan sejak saat keputusan tersebut kembali menjadi anggota perkumpulan dan pengurus pusat wajib untuk mengambil tindakan dalam rangka merehabilitasi anggota itu dalam jangka waktu 15 hari terhitung sejak tanggal kongres berakhir. Pelaksanaan sanksi atas pelanggaran kode etik oleh notaris dalam menjalankan jabatannya oleh DKN Notaris, menurut penulis memiliki kelemahan, oleh karena tidak mempengaruhi status notaris dalam melaksanakan tugas jabatannya. Sanksi tertinggi yang diberikan atas suatu pelanggaran, adalah pemberhentian dengan tidak hormat dari perkumpulan. Sanksi ini tidak berpengaruh karena notaris hanya diberhentikan Dari keanggotaan dan masih bisa melakukan pekerjaannya sebagai pejabat Notaris seperti biasa.

\section{Penutup}

Berdasarkan pembahasan diatas, terdapat 2 kesimpulan yakni, pertama, bentuk pelanggaran yang dilakukan oleh notaris sebagian besar melarang notaris untuk melakukan promosi atau publikasi terkait jabatan serta kantornya. DKN dapat menindak notaris yang melakukan pelanggaran Kode Etik Notaris, dengan cara memberi teguran, peringatan, pemberhentian sementara dari keanggotaan perkumpulan, pemberhentian dengan hormat dari keanggotaan perkumpulan, pemberhentian dengan tidak hormat dari keanggotaan perkumpulan. Kedua, pelanggaran dilakukan oleh notaris menimbulkan akibat hukum yaitu sanksi etik berupa teguran, peringatan, pemberhentian sementara dari keanggotaan perkumpulan, pemberhentian dengan hormat dari keanggotaan perkumpulan, pemberhentian dengan tidak hormat dari keanggotaan perkumpulan. Selain itu sanksi tersebut tidak langsung diberikan oleh DKN namun harus tetap berkoordinasi dengan MPN terlebih dahulu. Penjatuhan sanksi tersebut tidak 
langsung dijatuhkan melainkan dengan tata cara pelaksanaan yang diatur oleh Kode Etik Notaris. Notaris juga dapat melakukan banding apabila merasa tidak terima dengan keputusan yang diberikan. Sanksi tertinggi yang diberikan apabila terjadi pelanggaran adalah dikeluarkan dari anggota perkumpulan sedangkan sanksi tersebut hanya berpengaruh terhadap keanggotaan notaris saja bukan pada pekerjaannya, karena notaris hanya dipecat dari perkumpulan bukan dicabut ijin kerjanya sebagai notaris.

Sesuai dengan kesimpulan tersebut maka saran yang diberikan adalah, pertama, notaris hendaknya lebih mentaati aturan yang ada agar tidak ada lagi pelanggaran dan penjatuhan sanksi kepada notaris. Kedua, berkenaan dengan pelaksanaan sanksi yang diberikan kepada notaris yang melakukan pelanggaran, sebaiknya ada sanksi yang lain selain dikeluarkan dari anggota perkumpulan. Hal ini karena apabila hanya dikeluarkan dari anggota perkumpulan, notaris tersebut masih bisa melakukan kegiatannya sebagai notaris. Selain itu, kepada DKN untuk lebih meningkatkan pengawasan terhadap notaris agar pelanggaran Kode Etik semakin kecil. Peraturan yang mengatur tentang DKN juga perlu untuk semakin diperjelas sehingga tidak hanya mengacu pada Kode Etik Notaris saja.

\section{Daftar Pustaka}

\section{Buku}

Adjie, Habib Hukum Notaris Indonesia Tafsir Tematik Terhadap UU No. 30 Tahun 2004 Tentang Jabatan Notaris, Refika Aditama, Bandung, 2008.

Darus, M. Luthfan Hadi, Hukum Notariat Dan Tanggungjawab Jabatan Notaris, UII Press, Yogyakarta, 2017.

Fuady, Munir, Profesi Mulia (Etika Profesi Hukum bagi Hakim, Jaksa, Advokat, Notaris, Kurator dan Pengurus), PT. Citra Aditya Bakti, Bandung, 2005.

Notodisoerjo, R. Soegondo, Hukum Notariat di Indonesia Suatu Penjelasan, Rajawali, Jakarta, 1999.

Salim, H.S., Teknik Pembuatan Akta Satu Konsep Teoritis, Kewenangan Notaris, Bentuk dan Minuta Akta, PT Rajagrafindo Persada, Jakarta, 2015.

\section{Jurnal}

Arief Latief, "Main Bajak Karyawan Dan Kode Etik Notaris Dan/PPAT", Renvoi, Juli, 2004.

\section{Makalah}

Anggaran Dasar Ikatan Notaris Indonesia, Hasil Kongres Luar Biasa Bandung 27 Januari 2005.

\section{Peraturan Perundang-Undangan}

Kitab Undang-Undang Hukum Perdata

Undang-Undang Nomor 2 Tahun 2014 Atas Perubahan Undang-Undang Nomor 30 Tahun 2004 tentang Jabatan Notaris

Peraturan Menteri Hukum dan HAM RI. Nomor: M.02.PR.08.10 Tahun 2004 tentang Pelaksanaan Tugas Majelis Pengawas Notaris dan Tata Cara Pengangkatan Anggota, Pemberhentian Anggota, Susunan Organisasi, Tata Kerja dan Tata Cara Pemeriksaan Majelis Penga was Notaris. 


\section{Wawancara}

Wawancara dengan Jetti Widiastuti selaku Notaris Kota Tasikmalaya, 28 Januari 2021, pukul $09.00 \mathrm{WIB}$

Wawancara dengan Basri Jayasantan selaku Notaris Kabupaten Ciamis, 29 Januari 2021, pukul $09.30 \mathrm{WIB}$

Wawancara dengan Heri Hendriyana selaku Notaris Kota Tasikmalaya, 29 Januari 2021, pukul 10.30 WIB

Wawancara dengan Tiana selaku Notaris Kota Tasikmalaya, 29 Januari 2021, pukul 13.00 WIB 